\title{
The Relationship of Professional Burnout of the Teachers with the Peculiarities of the Value-Sense Sphere and Life Position
}

\section{Взаємозв'язок професійного вигорання педагогів з особливостями ціннісно- смислової сфери і життєвої позиції}

\author{
Nataliia Tavrovetska \\ Ph.D. in Psychology, Assistant Professor, Kherson State \\ University, Kherson (Ukraine) \\ ORCID ID: https://orcid.org/0000-0002-9497-7386 \\ Researcher ID: E-6605-2019 \\ E-mail: 1882181@gmail.com
}

\section{Наталія Тавровецька}

Кандидат психологічних наук, доцент, Херсонський державний університет, м. Херсон (Україна)

\section{ABSTRACT}

The aim of the article is to consider the theoretical and practical approaches in the study of professional and emotional burnout of the teachers in the context of the interrelation of their value-sense sphere and existential sensation. The concepts of "professional and emotional burnout» are analyzed from modern points of view, but they are based on the known theories of $\mathrm{H}$. Maslach and $N$. Vodopianova. It is noted that burnout in the broadest context, as a state of psycho-emotional and motivational exhaustion, is caused by the imbalance of expenditures and resources of professional activity, which affects the value-

Address for correspondence, e-mail: kpnu_lab_ps@ukr.net Copyright: (C) Tavrovetska Nataliia

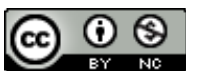


motivational basis of the regulation of behavior and leads to a long-term decrease in human efficiency in his or her vital sphere of life.

In order to determine the relationship between expressiveness of professional burnout and peculiarities of value-sense orientations, a complex of methods and techniques has been used, such as standardized questionnaire "Professional burnout» (by N. Vodopianova and O. Starchenkova), Questionnaire of Life Orientations (by O. Korzhova), the Schwartz' Theory, the Existence Scale (by A. Längle, K. Orgler), Subjective Alienation Questionnaire (by S. Maddi, in the adaptation of Ye. Osin), Maddi's Vitality Test, the Coping Test (by R. Lazarus and S. Folkman), methods of correlation and factor analysis.

The results of the research. It was determined that the acceptance and denial of a number of educators' values were significantly related to the symptoms of burnout - they can be their diagnostic markers, causes or effects. In general, burnout of teachers is accompanied by the desire for inner harmony, the attitude to health and safety as the leading principles of life, the strengthening of hedonistic attitudes, the desire for novelty.

The correlation analysis has been conducted, which established that the existential fullness of life directly correlated with the level of personal and professional achievements of teachers and was a factor that counteracted burnout. The expressiveness of burnout, on the contrary, correlates with manifestations of self-alienation and loss of sensation in different areas of life.

In conclusions, it was proved that there are common strategies of life, which regulate the relationships of professional burnout and value-sense orientations of employees and heads of secondary schools, such as exhaustion by selfimprovement; hyperhedonism; freedom of thoughts and actions; humanistic position; correspondence to social expectations.

Key words: professional burnout, emotional exhaustion, value-sense orientations, professional success.

\section{Вступ}

Питання дослідження емоційного вигорання виникло у психологічних науках у 70-х pp. XX ст. Дуже швидко 3 досліджень стресу в професіях рятувально-комунікативного типу воно поширилося на різні сфери зайнятості, а також на позапрофесійне життя. Сьогодні проблематику емоційного і професійного вигорання активно обговорюють лікарі

(C) Tavrovetska Nataliia

DOI (article): https://doi.org/10.32626/2227-6246.2020-49.296-321 
та психологи, розв'язують громадські організації й урядові органи, висвітлюють популярні ЗМІ - але проблема залишається гостроактуальною. Сьогодення нашого професійного й особистого життя швидко змінюється під впливом різноманітних стресорів, на які особистість не в змозі ефективно та рівноцінно реагувати. Достеменно невідомо, наскільки поширений цей стан (згідно з опитуванням 2017 р., його відчували понад половину українців); ситуація ускладнюється тим, що емоційне виснаження накопичується роками, упродовж яких людина втрачає здоров'я та контроль над власним життям. Висока поширеність і складні наслідки вигорання зумовлюють необхідність наукового пояснення причин його виникнення, механізмів розвитку i, найголовніше, шляхів відновлення.

Феномен «професійне вигорання» відомий давно, ще 3 початку минулого століття, він став символом індустріальної епохи. У 1970-х pр. це явище отримало влучну назву burnout завдяки автобіографічним публікаціям Н. Freudenberger (Freudenberger, 1974) про демотивацію волонтерів, які працюють у наркологічній клініці. Перші публікації викликали широкий громадський резонанс, що сприяло визнанню і поширенню цього терміна в академічному дискурсі. У загальному вигляді, вигорання визначається як глибока професійна й особистісна криза (Maslach, Jackson \& Leiter, 1996).

Саме з того часу в фокус уваги науковців потрапила загальна тенденція «зношування» спеціалістів сфери послуг (психологів, лікарів, учителів), чиї клієнти, пацієнти або учні, здається, не поліпшуються, не виліковуються та не вчаться. Визначення «професійне вигорання» стало використовуватися для позначення синдрому, що розвивається на тлі хронічного стресу і призводить до виснаження емоційно-енергетичних i особистісних ресурсів людини, яка працює у системі соціономічних професій. Сьогодні це поняття широко застосовується в соціальних науках, психологіiі, освіті та менеджменті.

(C) Tavrovetska Nataliia

DOI (article): https://doi.org/10.32626/2227-6246.2020-49.296-321 
DOI: https://doi.org/10.32626/2227-6246.2020-49 2020. випуск 49

Найгрунтовніший внесок у психологічне пояснення цього феномену внесли (і продовжують вносити) праці американської дослідниці С. Maslach (С. Maslach, 1976). Вигорання вона визначає як трикомпонентний психологічний синдром, що включає виснаження, цинізм і неефективність на робочому місці. Це індивідуальний досвід переживання стресу, що розглядається в контексті складних соціальних відносин і професійної позиції, уявлень людини про себе та про інших людей на роботі. На відміну від гострих стресових реакцій, які розвиваються у відповідь на конкретні критичні події, вигорання - це кумулятивна реакція на стресори поточної, повсякденної професійної діяльності, своєрідний «процес психологічної ерозії».

3'явилися перші комплексні дослідження, що підтверджують структуру емоційного вигорання та розкривають особливості його генезису в представників різних професій. Однією з найбільш теоретично обгрунтованих і методологічно вивірених стала праця «Синдром вигорання» Н. Водоп’янової й О. Старченкової (Водопьянова, 2013). Автори представили найновіші на той час західні теорії, провели аналіз широкого кола чинників, пов'язаних із професійним стресом і вигоранням, виклали результати власних емпіричних досліджень.

У 2016 p. C. Maslach i M. Leiter (Maslach \& Leiter, 2016) визначили, що вигорання «розвивається у відповідь на проблемні відносини між працівниками та їх робочими місцями», не звертаючись до будь-якої конкретної професійної сфери. В останні роки все впевненіше звучить думка про вигорання у життєвих сферах поза роботою: у веденні домашнього господарства, партнерське або батьківське вигорання. 3 часом було проголошено, що вигорання властиве не тільки соціономічним професіям, воно може виникати в інших професійних групах із високою психоемоційною напруженістю праці: військові, працівники МВС і МНС, підприємці.

(C) Tavrovetska Nataliia

DOI (article): https://doi.org/10.32626/2227-6246.2020-49.296-321 
Так, у своїй монографії «Психологія професійного вигорання підприємців» Л. Карамушка (Карамушка, 2018) приходить до висновку, що «існує зв'язок між низкою особистісних характеристик і професійним вигоранням підприємців». У процесі свого дослідження авторка виявляє, що понад третину опитаних підприємців мають високий рівень вираженості всіх складових професійного вигорання. Найвираженішою є така складова, як «редукція особистих досягнень». Дослідники Н. Гончаренко та М. Білоус (Гончаренко \& Білоус, 2018) визначають причини й симптоматику емоційного вигорання фармацевтичних працівників, сутність і специфіку психологічних аспектів їх професійної діяльності; установлюють їх особистісні та комунікативні якості й психологічні характеристики, що допомагають у роботі, та такі, що перешкоджають їх професійній діяльності. У результаті виявляють чинники, що можуть впливати на рівень розвитку емоційного вигорання: самопочуття, активність, настрій, тривожність, депресивність, невротичність.

Цікаве дослідження взаємозв'язку між симптомами професійного вигорання педагогів і сімейним статусом проводить група українських дослідниць Г. Фесун, Т. Нечитайло і Т. Канівець (Фесун, Нечитайло \& Канівець, 2019). Вони приходять до висновку, що «більшість симптомів професійного вигорання притаманні педагогам, у яких є двоє дітей. Імовірно, відповідальність за життя й добробут двох власних дітей, матеріальні труднощі збільшують психологічне навантаження на вчителів. Їх накопичення, зі свого боку, формує відчуття невдоволеності, роздратованості, що, як наслідок, зумовлює професійні кризи, виснаження та вигорання».

Отже, ми можемо констатувати, що постіндустріальна епоха, з властивим їй пріоритетом самореалізації й особистої відповідальності людини за своє життя і кар'єру, ускладнила механізми розвитку вигорання. Це актуалізує (C) Tavrovetska Nataliia

DOI (article): https://doi.org/10.32626/2227-6246.2020-49.296-321 
дослідження ціннісно-смислових аспектів життєдіяльності, пов'язаних із професійними стресами та їх подоланням.

Мета статті - висвітлити емпірично й статистично доведені чинники зв'язку професійного вигорання з особливостями ціннісно-смислових орієнтацій і життєвої позиції педагогів.

\section{Завдання статті}

1. Представити результати взаємозв'язку між вираженістю професійного вигорання й особливостями ціннісносмислових орієнтацій.

2. Розкрити результати факторизації професійного вигорання з особливостями ціннісно-смислової сфери і життєвої позиції (на прикладі педагогів).

\section{Методи та методики дослідження}

Було проведено дослідження педагогів закладів загальної освіти і спеціалізованих шкіл м. Херсона. Опитування проходило в першому навчальному семестрі (листопад 2019 - січень 2020 рр.). Учасники були заздалегідь ознайомлені з метою дослідження і дали згоду на використання своїх даних у наукових цілях. Вибірку склали 86 осіб, серед яких - 20 керівників закладів загальної освіти (директори та заступники директорів): 14 жінок і 6 чоловіків; 66 працівників (вчителі, вихователі, психологи, соціальні працівники) середньої та старшої школи; переважно жінки $(75,7 \%)$, що відображає демографічну особливість цієї професії. Вік учасників дослідження - від 26 до 58 років (середній вік 33,8 року), стаж педагогічної роботи - від 5 до 36 років.

Для діагностики симптомів вигорання було застосовано стандартизований опитувальник «Професійне вигорання» (Н. Водоп'янової й О. Старченкової) для фахівців соціономічних професій, розроблений у 2003 р. В основі методики - вигорання як динамічний процес, розподілений у часі

(C) Tavrovetska Nataliia

DOI (article): https://doi.org/10.32626/2227-6246.2020-49.296-321 
на окремі фази: емоційне виснаження, деперсоналізація, редукція персональних досягнень. Відповідно, опитувальник містить три симптоматичні шкали, що характеризують фазову динаміку вигорання. Про наявність порушення свідчать високі оцінки за субшкалами емоційного виснаження i деперсоналізації, низькі - за шкалою «Професійна ефективність» (редукція персональних досягнень).

Для діагностики життєвої позиції й ціннісних орієнтацій працівників освітніх установ було використано набір опитувальників.

1. Опитувальник життєвих орієнтацій (О. Коржової) дає змогу зробити висновок про особливості життєвого самовизначення. Шкали методики відображають базові компоненти життєвих орієнтацій: мінливість - стабільність (прагнення змінюватися або залишатися незмінним); внутрішній - зовнішній локус контролю (прийняття або делегування відповідальності); спрямованість на освоєння внутрішнього - зовнішнього світу (прагнення до самовдосконалення або практичної діяльності); рухливість - інертність (прагнення до нового або звичного).

2. Методика Ш. Шварца для вивчення цінностей особистості, розроблена на основі авторської теоретичної моделі, - пояснює цінності як універсальні мотиваційні типи, присутні в усіх культурах і соціальних шарах. Методика дає оцінку 10 шкал, які представляють життєво важливі вітальні й базові цінності (потреби окремого індивіда, суспільства, людського виду загалом).

3. Шкала екзистенції (А. Ленглі, К. Орглер) - представляє екзистенціально-аналітичний підхід і призначена для оцінки якості життя людини з точки зору її свідомості й наповненості. Загальний показник опитувальника - екзистенційна наповненість - говорить про здатність «справлятися із самим собою і зі світом і здатність піти на внутрішні й зовнішні вимоги і пропозиції, співвідносячи їх із власними цінностями» .

(C) Tavrovetska Nataliia

DOI (article): https://doi.org/10.32626/2227-6246.2020-49.296-321 
4. Опитувальник суб'єктивного відчуження (С. Мадді; в адаптації Є. Осіна, 2007) - використано для вимірювання переживання індивідом екзистенційного неврозу і смисловтрати в різних сферах життя: відчуження від роботи, суспільства, в міжособистісних відносинах, від сім'ї та самого себе.

5. Тест життєстійкості С. Мадді (російськомовна адаптація виконана у 2006 р. Д. Леонтьєвим і О. Расказовою). Жииттєстійкість включає в себе три компоненти: залученість - визначає задоволення від власної діяльності, що передбачає переконаність у доброті світу і впевненість у власних силах; контроль - представляє вибір власного шляху, переконаність у тому, що власні зусилля дають можливість впливати на результат того, що відбувається; прийняття виклику - відображає переконаність індивіда у тому, що все, що з ним трапляється (як добре, так і погане), сприяє його розвитку за рахунок знань і досвіду.

6. Копінг-тест (Р. Лазаруса і С. Фолкман) - дає змогу вивчити способи подолання труднощів у різних сферах психічної діяльності. Він включає такі копінг-стратегії: конфронтація, дистанціювання від проблеми, самоконтроль емоцій і поведінки, пошук соціальної підтримки, прийняття відповідальності, планування вирішення проблеми, втечауникнення, позитивна переоцінка.

Отримані дані було оброблено за допомогою кореляційного і факторного аналізу (програма Microsoft Excel 2010 i SPSS 18.0).

\section{Результати та дискусії}

Аналіз результатів ми почали з інтерпретації за опитувальником «Професійне вигорання» (Н. Водоп'янової й О. Старченкової). 3 табл. 1 бачимо, що хоча середні показники симптомів вигорання у керівників трохи вищі, ніж у працівників, загалом різниця інтегрального показника не має статистичної значущості. Безсумнівно, що рівень про-

(C) Tavrovetska Nataliia

DOI (article): https://doi.org/10.32626/2227-6246.2020-49.296-321 
DOI: https://doi.org/10.32626/2227-6246.2020-49

фесійного стресу керівництва вищий, ніж у рядових працівників. Їх діяльність супроводжується постійним психічним напруженням, участю у вирішенні конфліктних ситуацій, необхідністю прийняття управлінських рішень, відповідальністю за результати роботи всієї школи, високими вимогами до професійних та особистих якостей, ненормованим робочим графіком тощо. Але при цьому директори мають більшу винагороду за роботу (у вигляді соціальних і матеріальних ресурсів), що допомагає зберігати необхідний адаптаційний баланс. Свідомість власних досягнень допомагає керівникам нейтралізувати емоційне виснаження. Отже, отримані результати не дають підстав говорити про те, що керівники в системі освіти мають ризик вигорання вищий, ніж рядові працівники тієї ж сфери.

Таблиия 1

Порівняльний аналіз симптомів вигорання (M $\pm \mathrm{SD})$ серед працівників і керівників закладів загальної освіти

\begin{tabular}{|l|c|c|c|}
\hline \multicolumn{1}{|c|}{ Шкали } & Працівники & Керівники & $\begin{array}{c}\text { Розбіжнос- } \\
\text { ті, U* }\end{array}$ \\
\hline Інтегральний показник & $4,75 \pm 2,19$ & $5,31 \pm 1,31$ & 0,22 \\
\hline Емоційне виснаження & $19,51 \pm 7,96$ & $20,23 \pm 7,65$ & 0,69 \\
\hline Деперсоналізація & $8,45 \pm 5,36$ & $12,50 \pm 4,62$ & $\mathbf{0 , 0 1}$ \\
\hline Професійна успішність & $33,70 \pm 7,57$ & $36,25 \pm 6,68$ & 0,34 \\
\hline
\end{tabular}

Прилітка: * - вказана значущість U-критерію Манна - Вітнi, $\mathrm{p} \leq 0,05$.

Загалом, поширеність синдрому вигорання у вибірці відносно невелика - не більше $18 \%$ серед рядових працівників і 15\% серед керівництва. При цьому серед працівників число респондентів із низьким рівнем вигорання перевищує число «вигорілих» (загалом, розподіл близький до нормального). Розподіл даних у групі керівників відрізняється від нормального, а також від очікуваного на підставі процесуально-динамічної теорії вигорання. Усі керівники демон(c) Tavrovetska Nataliia

DOI (article): https://doi.org/10.32626/2227-6246.2020-49.296-321 
струють високий або середній рівні професійної ефективності - цей факт зрозумілий, оскільки вони мають очевидні кар'єрні успіхи і досягнення. Крім того, для керівників закладів загальної освіти характерний підвищений показник шкали «Деперсоналізація» (порівняно з працівниками різниця значуща при $\mathrm{p}=0,01)$. З゚оден керівник не отримав низьку оцінку, зате перевищення нормативних показників виявлено у $40 \%$. У всіх цих випадках висока деперсоналізація поєднується з емоційною залученістю у роботу (низькою виразністю симптому виснаження).

Швидше за все, деперсоналізація керівників не є симптомом або наслідком вигорання на роботі. Це компонент інших особистісних порушень або професійних деструкцій, характерних для менеджерів. У вибірці керівників прояв деперсоналізації прямо пов'язаний із самооцінкою професійної ефективності (хоча кореляція не досягає статистично значущого рівня). Це суперечить логіці розвитку процесу вигорання відповідно до моделі C. Maslach i S. Jackson (Maslach \& Jackson, 1996). Такий взаємозв'язок можна пояснити тим, що ефективних керівників дратують повільні й некомпетентні співробітники, вони не дозволяють собі проявляти емоції у відносинах із колегами (неупередженість асоціюється з нечутливістю), використовують підлеглих як інструмент для досягнення поставлених організаційних цілей. Усе це свідчить про те, що механізм розвитку вигорання і структура його окремих компонентів мають професійну специфіку. Отримані результати розширюють ці уявлення, ïх слід ураховувати в психологічній діагностиці різних категорій керівників.

У результатах кореляційного аналізу звертає на себе увагу негативна кореляція показника професійної успішності та стажу роботи (ця тенденція характерна для всіх категорій працівників освітніх установ). Тобто, з віком відбувається не тільки природне емоційне виснаження, а й знецінення своєї професійної діяльності.

(C) Tavrovetska Nataliia

DOI (article): https://doi.org/10.32626/2227-6246.2020-49.296-321 
Кореляції окремих проявів редукції професійних досягнень у загальній вибірці педагогів $(\mathrm{N}=86)$

\begin{tabular}{|c|c|c|c|c|c|}
\hline $\begin{array}{c}\text { Деякі пункти } \\
\text { шкали «Професійна } \\
\text { ефективність» }\end{array}$ & 焉 & 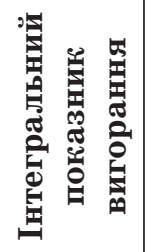 & 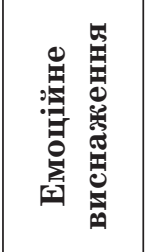 & 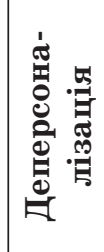 & 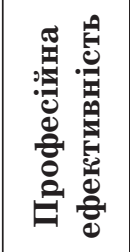 \\
\hline $\begin{array}{l}\text { 4. Результати моєї роботи } \\
\text { не варті тих зусиль, які я } \\
\text { докладаю }\end{array}$ & $-0,32 * *$ & $-0,43 * * *$ & $-0,18$ & 0,04 & $0,51 * * *$ \\
\hline $\begin{array}{l}\text { 7. У розмові з агресивними } \\
\text { або конфліктними праців- } \\
\text { никами я вмію домовитись } \\
\text { і не конфліктувати }\end{array}$ & $-0,23 *$ & $-0,16$ & $-0,35 * *$ & 0,18 & $0,36 * *$ \\
\hline $\begin{array}{l}\text { 9. Я вмію зацікавити моїх } \\
\text { підлеглих (партнерів) }\end{array}$ & $-0,43 * * *$ & $-0,17$ & $-0,22^{*}$ & $0,24 \%$ & $0,60 * * *$ \\
\hline $\begin{array}{l}\text { 12. Я працюю із задоволен- } \\
\text { ням, у мене багато планів, } \\
\text { пов'язаних із моїм профе- } \\
\text { сійним майбутнім. Я вірю } \\
\text { в їх здійснення }\end{array}$ & $-0,14$ & $-0,46 * * *$ & $-0,51 * * *$ & 0,07 & $0,58 * * *$ \\
\hline $\begin{array}{l}\text { 17. Я легко можу створити } \\
\text { атмосферу добра та співп- } \\
\text { раці у колективі }\end{array}$ & $-0,25 *$ & 0,13 & 0,00 & 0,21 & 0,12 \\
\hline $\begin{array}{l}\text { 18. Я легко спілкуюся на } \\
\text { роботі з усіма незалежно } \\
\text { від їх амбіцій, емоційного } \\
\text { стану та манер }\end{array}$ & 0,05 & 0,05 & 0,06 & 0,13 & 0,13 \\
\hline $\begin{array}{l}\text { 19. Я задоволений свої- } \\
\text { ми успіхами на роботі й у } \\
\text { житті }\end{array}$ & $-0,15$ & $-0,26 *$ & $-0,12$ & $-0,15$ & $0,22 *$ \\
\hline $\begin{array}{l}\text { 21. Я можу ще багато чого } \\
\text { зробити у своєму житті }\end{array}$ & $-0,26 *$ & $-0,36 * *$ & $-0,45 * * *$ & 0,14 & $0,67 * * *$ \\
\hline
\end{tabular}

$$
\text { Примітка: *-p } \leq 0,05 ; * *-\mathrm{p} \leq 0,01 ; * * *-\mathrm{p} \leq 0,001 .
$$

(C) Tavrovetska Nataliia 
Кореляційний аналіз виявив, що з накопиченням професійного стажу (цей показник, своєю чергою, тісно пов'язаний із віком) значуще знижується оцінка зусиль, відданих роботі; вміння уникати конфліктів; здатність мотивувати партнерів і підлеглих; створювати доброзичливу атмосферу співробітництва, а також оцінка власних життєвих перспектив і можливостей.

Щодо інтерпретації показників шкали «Професійна ефективність» Н. Водоп'янова і співавтори (Водопьянова, 2013) відзначають вплив віку й етапу становлення людини в професії: період професійної адаптації пов’язаний з усвідомленням молодим фахівцем деякої недостатності своїх знань і умінь, тобто низькі бали за шкалою у педагогів-початківців не є симптомом вигорання. У сформованих працівників на етапі зрілості й пізньої зрілості низькі бали за окресленою шкалою свідчать про знижену самооцінку досягнутих результатів і вторинне зниження продуктивності через зміни ставлення до роботи. Наші результати підтверджують ці спостереження.

При порівнянні загальної картини вигорання педагогічних працівників із даними попередніх досліджень ми виявили, що наша статистика більш оптимістична. Так, у дослідженні О. Бондарчук (Бондарчук, 2008) високий рівень вигорання зафіксовано у $28 \%$ керівників освітніх установ. Слід ураховувати, що на статистику професійного вигорання сильно впливає час проведення дослідження: робота педагога має яскраво виражений річний цикл із піком утоми в квітні-червні та подальшим періодом відновлення.

Кореляційний аналіз виявив низку значущих взаємозв'язків між вигоранням і вищими особистісними диспозиціями. У табл. 3 відображено значущі кореляції (ми орієнтувалися на критичний показник коефіцієнта кореляції Пірсона для вибірки обсягом 80 осіб: 0,815 при $\mathrm{p} \leq 0,10$; 0,220 при $\mathrm{p} \leq 0,05 ; 0,286$ при $\mathrm{p} \leq 0,01 ; 0,361$ при $\mathrm{p} \leq 0,001$ ).

(C) Tavrovetska Nataliia DOI (article): https://doi.org/10.32626/2227-6246.2020-49.296-321 
Кореляції показників професійного вигорання з результатами особистісних опитувальників

\begin{tabular}{|c|c|c|c|c|}
\hline $\begin{array}{l}\text { Шкали особистісних } \\
\text { опитувальників }\end{array}$ & 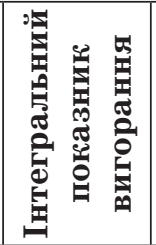 & 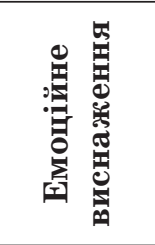 & 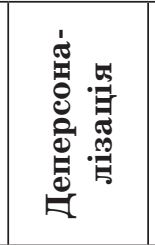 & 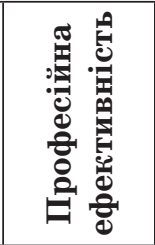 \\
\hline 1 & 2 & 3 & 4 & 5 \\
\hline Вiк & - & $0,38 * * *$ & $0,29 * *$ & $-0,28 * *$ \\
\hline Професійний стаж & - & $0,28 * *$ & $0,23 *$ & $-0,25 *$ \\
\hline \multicolumn{5}{|c|}{ Методика Ш. Шварца } \\
\hline Традиції & - & - & $-0,26 *$ & - \\
\hline Самостійність & $0,24 *$ & $0,31 * *$ & - & - \\
\hline Гедонізм & $0,22 \%$ & 0,19 & - & - \\
\hline Безпечність & $0,25 \%$ & $0,33 * *$ & - & $-0,32 * *$ \\
\hline \multicolumn{5}{|c|}{ Шкала екзистенції А. Ленгле, К. Орглер } \\
\hline Самодистанціювання & $-0,30 * *$ & $-0,19$ & - & 0,21 \\
\hline Самотрансценденція & $-0,20$ & - & - & $0,23 *$ \\
\hline Відповідальність & $-0,26 *$ & - & - & $0,25 *$ \\
\hline Екзистенційна наповненість & $-0,24 *$ & - & - & $0,26 *$ \\
\hline \multicolumn{5}{|c|}{ Опитувальник життєвих орієнтацій О. Коржової } \\
\hline Жћиттева мінливість & $0,40 * * *$ & $0,51 * * *$ & - & $-0,39 * * *$ \\
\hline Внутрішній локус контролю & - & - & $0,29 * *$ & - \\
\hline $\begin{array}{l}\text { Спрямованість на освоєння } \\
\text { внутрішнього - зовнішнього } \\
\text { світу }\end{array}$ & $0,48 * * *$ & $0,41 * * *$ & - & $-0,51 * * *$ \\
\hline Життєва рухливість & - & - & $0,44 * * *$ & - \\
\hline $\begin{array}{l}\text { Загальний показник суб’єкт- } \\
\text { об’єктних орієнтацій }\end{array}$ & $0,31 * *$ & - & $0,03 * *$ & - \\
\hline
\end{tabular}

C Tavrovetska Nataliia 
Продовження табл. 3

\begin{tabular}{|l|c|c|c|c|}
\hline \multicolumn{1}{|c|}{1} & 2 & 3 & 4 & 5 \\
\hline $\begin{array}{l}\text { Загальний показник відчу- } \\
\text { ження }\end{array}$ & - & - & - & $-0,22 *$ \\
\hline Відчуження від роботи & - & - & - & $-0,21$ \\
\hline Відчуження від суспільства & - & - & - & $-0,23 *$ \\
\hline Відчуження від інших людей & - & - & 0,19 & - \\
\hline Відчуження в родині & $0,38 * * *$ & $0,34 * *$ & - & $-0,19$ \\
\hline Відчуження від самого себе & - & - & - & $-0,20$ \\
\hline
\end{tabular}

Тест життєстійкості С. Мадді

\begin{tabular}{|l|c|c|c|c|}
\hline Залученість & $-0,31 * *$ & $-0,29 * *$ & - & $0,46 * * *$ \\
\hline Контроль & $-0,26 *$ & $-0,28 *$ & 0,18 & $0,33 * *$ \\
\hline Прийняття ризику & $-0,21$ & $-0,26 *$ & - & $0,30 * *$ \\
\hline Загальна життєстійкість & $-0,24 *$ & $-0,25 *$ & - & $0,39 * * *$ \\
\hline
\end{tabular}

Прилітка: у таблиці відображено показники, абсолютне значення яких більше $0,185: *-\mathrm{p} \leq 0,05 ; * *-\mathrm{p} \leq 0,01 ; * * *-$ $\mathrm{p} \leq 0,001$.

На підставі даних табл. 3 відзначимо кілька важливих тенденцій.

1. Визнання та заперечення низки ціннісних орієнтирів значуще пов'язано із симптомами вигорання - вони можуть бути їх діагностичними маркерами, причинами або наслідками. Загалом вигорання супроводжується прагненням до внутрішньої гармонії, ставленням до здоров'я і безпеки як провідних життєвих принципів, посиленням гедоністичних установок, прагненням до новизни. Ми вважаємо, що подібні ціннісні орієнтації приходять унаслідок переоцінки життєвих принципів у процесі розвитку кризи і є за своєю природою захисними й компенсуючими. Орієнтація на вибір власних бажань і цілей може лежати в основі вигорання, оскільки активне просування своїх інтересів призводить до «витрачання себе».

(C) Tavrovetska Nataliia

DOI (article): https://doi.org/10.32626/2227-6246.2020-49.296-321 
Вигорання прямо пов'язано з декларованою i реально діючою цінністю «Безпека». Чим більше емоційно виснажена людина, тим більше значення для неї має безпека і стабільність суспільства, відносин, самої себе. В основі цього зв'язку - функція самозбереження.

Ціннісний ідеал «Самостійність у думках і діях» тісно корелює з емоційним виснаженням і загальним рівнем вигорання. Подібний зв'язок виявлений і з показником «Гедонізм», але механізм формування цих залежностей, швидше за все, різний. Відомо, що одним із наслідків вигорання $€$ потурання власним слабкостям, прагнення до комфорту, пасивного відпочинку і чуттєво-матеріальних задоволень (Левит, 2016).

2. Екзистенційна наповненість життям прямо корелює з рівнем особистих і професійних досягнень педагогів $\mathrm{i}$, очевидно, є чинником, що протидіє вигоранню. Вираженість вигорання, навпаки, корелює з проявами самовідчуження i втратою сенсу в різних життєвих сферах.

3. Найсильніші й глобальні кореляції стосуються показників вигорання і життєстійкості. Професійна ефективність супроводжується високим рівнем залученості, контролем над життєвими обставинами і прийняттям ризику. Емоційне виснаження тягне за собою зниження всіх компонентів життєстійкості.

4. Жоден із показників копінг-стратегій не продемонстрував значних кореляцій із показниками вигорання.

5. Показники життєвих орієнтацій опитувальника О. Коржової демонструють складну структуру кореляцій 3 окремими симптомами вигорання. Загалом суб'єктна орієнтованість виявилася чинником, що провокує або підсилює вигорання фахівців, і це можна пояснити прискореним витрачанням життєвих ресурсів - фізичних, емоційних, мотиваційних, когнітивних тощо.

Отримані факти суперечать поширеній думці про суб'єктності як основи особистісного зростання та психологічного (C) Tavrovetska Nataliia

DOI (article): https://doi.org/10.32626/2227-6246.2020-49.296-321 
благополуччя. Активна життєва позиція приймається та заохочується у більшості культур як найбільш соціально прийнятний тип поведінки і спосіб мислення. Але для самої особистості надмірна залученість небезпечна закономірними наслідками у вигляді емоційного виснаження, розчарування, цинізму, негативізму, знецінення своїх колишніх цілей і досягнень.

Для виявлення внутрішньої структури взаємозв'язків змінних ми провели факторний аналіз (без обертання). У результаті було виокремлено п'ять латентних факторів, які в сукупності пояснюють 84\% дисперсії. Як значущі факторні навантаження ми розглядали коефіцієнти кореляції ознаки 3 фактором, що мають абсолютне значення більше 0,5.

Перший фактор має власну вагу 11,3 і детермінує 25,7\% сумарної дисперсії. Головні факторні навантаження належать компонентам вигорання: емоційному виснаженню і редукції професіоналізму, а також показникам суб'єктоб’єктних орієнтацій - життєвій мінливості (прагненню змінюватися) і спрямованості на освоєння внутрішнього світу (прагненню до самовдосконалення). Ці ознаки супроводжує зниження життєстійкості за рахунок відсутності залученості, замість якої приходить відчуття відчуження, відчуття себе «поза» життям. Фактор отримав назву «Виснаження самовдосконаленням» .

Зазначений фактор позитивно корелює 3 професійним стажем (віком) $(0,720)$, ціннісною орієнтацією на досягнення внутрішньої гармонії (бути в злагоді з собою) $(0,730)$, вираженістю базової цінності «Безпека» $(0,787)$. У цьому випадку важко сказати, чи є вигорання причиною життєвої орієнтації на зміни, або навпаки, завзяте прагнення до самовдосконалення спричиняє вигорання. Фактор негативно корелює з показниками екзистенційної наповненості $(-0,599)$ (окрім шкали «Свобода»), що свідчить про суміжну кризу, відчуття порожнечі й безглуздості життя; це підтверджується прямими кореляціями з окремими різновидами (C) Tavrovetska Nataliia DOI (article): https://doi.org/10.32626/2227-6246.2020-49.296-321 
DOI: https://doi.org/10.32626/2227-6246.2020-49

самовідчуження: від сім’ї $(0,585)$, від самого себе $(0,515)$. Останне можна трактувати як замінник традиційного симптому деперсоналізації, який не увійшов до фактора. У такому випадку це загальний життєвий цинізм і втрата цілей, які раніше були важливі для індивіда.

Другий фактор має власну вагу 10,8 і детермінує 24,6\% сумарної дисперсії. Факторні навантаження частково перетинаються зі змістом фактора 1 , але мають протилежний знак: заперечення цінності внутрішньої гармонії та відсутність проявів самовідчуження. Провідна роль тут належить гедонізму $(0,926)$, слідуванню власним бажанням як декларованій цінності й реальному принципу поведінки. Це поєднується з вираженим прагненням до новизни (життєва рухливість $(0,801)$ і цінність стимуляції $(0,646))$, прагненням не підкорятися традиціям $(-0,723)$, загальноприйнятим соціальним нормам і життєвим обставинам. Це своєрідний різновид активної життєвої позиції, у якій активність спрямована на егоїстичне забезпечення бажань індивіда. Деперсоналізація $(0,557)$ логічно вписується в окреслену тенденцію як знеособлення оточуючих $(-0,878)$, негативне і формальне ставлення до людей, що становлять професійне коло спілкування. Це сучасний тип споживацтва - «брати від життя yce» .

Наявність у факторі 2 таких показників, як «Деперсоналізація» $\mathrm{i}$ «Відчуження від роботи» $(-0,580)$, свідчить про те, що означений тип життєвої позиції - це не відкрита і радісна взаємодія зі світом, а самозакоханий егоїзм, споживацька позиція. Власні потреби людини стають вище приписів суспільства й інтересів інших людей, які розглядаються лише як перешкоди для вільної поведінки. Фактор позитивно корелюе із загальним показником опитувальника копінг-поведінки $(0,615)$, що свідчить про стресовий характер зазначеної життєвої стратегії. Фактор отримав назву «Гіпергедонізм».

(C) Tavrovetska Nataliia

DOI (article): https://doi.org/10.32626/2227-6246.2020-49.296-321 
Описані два фактори є прихованою основою взаємозв'язку між вигоранням і життєвою (ціннісно-смисловою) орієнтацією особистості. У зв'язку з отриманими результатами підкреслимо, що А. Ленглі (Лэнгле, 2008) розглядає емоційне вигорання як особливу форму екзистенційного вакууму результат того, що людина упродовж тривалого часу не проживає цінностей у професії, «виконання обов’язку без переживань». 3 іншого боку, відомо, що вигорання розвивається у найбільш захоплених своєю роботою фахівців: «надмірна захопленість роботою, ставка на професійну діяльність як на основний спосіб самореалізації, обмеження інших життєвих сфер й інтересів, замикання внутрішніх смислів на якій-небудь одній зі сторін власного життя значно збільшує суб'єктивну ціну помилки, невдачі, перетворюючи їі в особисту катастрофу, що зачіпає всю ціннісну, смислову сферу, перетворюючись в екзистенційну проблему втрати сенсу» (Бессонова \& Лазебная, 2013).

Наступні фактори прямо не стосуються вигорання, але являють собою цікаві варіанти життєвих стратегій, «звільняють» людину від ризику професійного вигорання.

Третій фактор (власна вага 6,$6 ; 15,5 \%$ сумарної дисперсіi) відображає свободу $(0,791)$ як головний ціннісний вектор, що лежить в основі суб’єктної активності $(0,772)$ і наповненості життя сенсом $(0,564)$. Головну роль тут відіграє екзистенційна свобода як здатність вибирати власні цілі, приймати рішення на основі власних цінностей і знаходити відповідні можливості дій. Прийняття ризику (як позитивних, так і негативних компонентів отриманого досвіду) $(0,766)$ забезпечує загальну життєстійкість $(0,540)$. Декларована цінність самостійності втілена в реальну поведінку. Особливістю системи цінностей є виражена орієнтація на ідеали досягнень, стимуляції та самостійності при відмові від просоціальної спрямованості. Фактор отримав назву «Свобода думок і вчинків».

(C) Tavrovetska Nataliia

DOI (article): https://doi.org/10.32626/2227-6246.2020-49.296-321 
Четвертий фактор (власна вага 4,6; 10,5\% сумарної дисперсіі) цікавий тим, що має негативну кореляцію 3 показником деперсоналізації $(-0,505)$ і відчуження від роботи $(-0,595)$, тобто може розглядатися як сила, що протидіє розвитку цих негативних симптомів. Він являє собою ціннісний ідеал універсалізму (розуміння, терпимість, захист благополуччя всього людства і природи) $(0,684)$ i втілену доброту (збереження благополуччя людей, із якими індивід перебуває в безпосередньому контакті) $(0,632)$. Гуманістично-альтруїстична спрямованість, турбота про інших є професійно-важливою якістю педагогічних працівників. Цей фактор ми назвали «Гуманістична позиція» .

П'ятий фактор (власна вага 3,$3 ; 7,5 \%$ сумарної дисперсіiі) представляє тенденції, протилежні описаним у фактоpi 3. Це відмова від самостійності $(-0,541)$, орієнтація на підтримку традицій $(0,605)$ і конформність у соціальній поведінці $(0,512)$. В основі такої поведінки лежить свідома відмова від самостійності й самодистанціювання $(0,503)-$ здатність людини відійти на дистанцію стосовно самої себе, відсунути свої бажання, уявлення та почуття. Це забезпечує групову солідарність. Описана стратегія, хоча й дещо суперечить положенням психології суб'єктності, проте є досить ефективною: вона орієнтована на досягнення успіху і позитивно корелює із загальним показником життєстійкості. Фактор отримав назву «Відповідність соціальним очікуванням» .

\section{Висновки}

Проведене дослідження дало нам змогу сформулювати низку теоретичних і практичних висновків відповідно до поставлених завдань.

1. На основі теоретичного огляду наукової літератури ми розумітимемо вигорання в найширшому контексті - як набутий стан психоемоційного та мотиваційного виснаження, спричинений дисбалансом витрат і ресурсів професійної (c) Tavrovetska Nataliia

DOI (article): https://doi.org/10.32626/2227-6246.2020-49.296-321 
діяльності, що зачіпає ціннісно-мотиваційні основи регуляції поведінки та призводить до тривалого зниження ефективності людини в значущій для неї сфері життєдіяльності. У контексті індивідуального подолання проблеми вигорання найперспективнішим є екзистенціальний підхід до вигорання, що висуває на перший план порушення ціннісно-смислової регуляції професійної діяльності, втрату мотивації та переживань, що складають сенс життя людини. Це відкриває широкі можливості для надання психологічної допомоги. Характерною рисою особистостей, стійких до професійного вигорання, є їх здатність формувати і підтримувати в собі позитивні, оптимістичні установки та цінності: щодо самих себе, інших людей і життя взагалі.

2. Установлено, що активна життєва позиція приймається як найбільш соціально прийнятний тип поведінки і спосіб мислення. Однак для самої особистості надмірна залученість несе небезпеку закономірними хворобливими наслідками у вигляді емоційного виснаження, розчарування, цинізму, негативізму, знецінення своїх колишніх цілей i досягнень. Кореляційні зв'язки вказують на такі тенденції у вибірці педагогів: чим більше емоційно виснажена людина, тим більше значення для неї має безпека і стабільність суспільства, відносин, самої себе. Екзистенційна наповненість життя виступає чинником, який протидіє вигоранню, оскільки значуще корелює з рівнем особистих і професійних досягнень педагогів. Високі показники вигорання, навпаки, корелюють із проявами самовідчуження і втратою сенсу в різних життєвих сферах. Як підсумок кореляційних зв'язків установлено, що емоційне виснаження тягне за собою зниження всіх компонентів життєстійкості.

3. Проведене дослідження виявило п'ять загальних стратегій життєтворення, які регулюють взаємозв'язок професійного вигорання і ціннісно-смислових орієнтацій працівників і керівників закладів загальної освіти: виснаження самовдосконаленням; гіпергедонізм; свобода думок і вчин-

(C) Tavrovetska Nataliia

DOI (article): https://doi.org/10.32626/2227-6246.2020-49.296-321 
ків; гуманістична позиція; відповідність соціальним очікуванням. Порушення смисложиттєвих орієнтацій проявляється в незадоволеності процесом і результатом свого життя в теперішньому та минулому. Вигорання супроводжується відсутністю спрямованості у майбутне, знеціненням мрій i цілей, які надають сенс життю - саме цей аспект повинен бути мішенню психологічного впливу.

Отримані результати відкривають широкі можливості для психологічної допомоги та профілактики. Важливу перспективу подальших досліджень ми вбачаємо у проведенні зрізу симптоматики професійного вигорання вчителів (на початку і в кінці навчального року, в періоди семестрової атестації, під час дистанційної роботи), а також у відстеженні психологічних чинників, що провокують і уповільнюють розвиток вигорання упродовж робочого циклу.

\section{Література}

Бессонова Ю. В., Лазебная Е. О. Ценностные предпосылки выгорания субъекта труда. Выгорание и профессионализаиия: сб. науч. трудов / под ред. В. В. Лукьянова и др. Курск : КГУ, 2013. С. 29-43. Бондарчук О. I. Соціально-психологічні основи особистісного розвитку керівників загальноосвітніх навчальних закладів у професійній діяльності: автореф. дис. ... д-ра психол. наук: 19.00.05. Київ, 2008. $34 \mathrm{c}$.

Водопьянова Н. Е., Старченкова Е. С., Наследов А. Д. Стандартизированный опросник «Профессиональное выгорание» для специалистов социономических профессий. Вестник Санкт-Петербургского университета. Серия 12. Социология. 2013. Вып. 4. С. 17-27.

Гончаренко Н. В., Білоус М. В. Психологічні особливості прояву синдрому «емоційного вигорання» у провізорів-інтернів. Проблели сучасної психології: Збірник наукових праць Кам'янець-Подільського національного університету імені Івана Огієнка, Інституту психологї імені Г. С. Костюка НАПН України / за наук. ред. С. Д. Максименка, Л. А. Онуфрієвої. Кам'янець-Подільський : Аксіома, 2018. Вип. 40. С. 62-80. DOI 10.32626/2227-6246.201840.62-80.

Карамушка Л. М., Гнускіна Г. В. Психологія професійного вигорання підприємців: монографія. Київ : Логос, 2018. 198 с.

(C) Tavrovetska Nataliia

DOI (article): https://doi.org/10.32626/2227-6246.2020-49.296-321 http://journals.uran.ua/index.php/2227-6246 
Левит Л. З. Психология развития и реализации жизненного потенциала субъекта: дис. ... д-ра психол. наук: 19.00.01. Киев, 2016. 605 с.

Лэнгле А. Эмоциональное выгорание с позиций экзистенциального анализа. Вопросы психологии. 2008. № 2. С. 3-16.

Фесун Г., Нечитайло Т., Канівець Т. Взаємозв'язок компонентів синдрому «професійного вигорання» з особливостями сімейного статусу в педагогів. Психологічні перспективи. 2019. Вип. 34. С. 232-248. URL : https://doi.org/10.29038/2227-1376-2019-34-232-248.

Freudenberger, H. (1974). Staff Burnout. Journal of Social Issues, 30, 159-165. DOI 10.1111/j.1540-4560.1974.tb00706.x.

Maslach, C. (1976). Burned-out. Human Behavior, 9, 16-22.

Maslach, C., Jackson, S. E., \& Leiter, M. P. (1997). The Maslach burnout inventory Manual. Evaluating stress, (pp. 191-218). Palo Alto, California : Consulting Psychologists Press. $34 \mathrm{p}$.

Maslach, C., \& Leiter, M. P. (2016). Burnout. In G. Fink (Ed.). Handbook of Stress: Vol. 1. Stress: Concepts, Cognition, Emotion, and Behavior, (pp. 351-357. Academic Press. DOI 10.1016/B978-0-12-8009512.00044-3.

\section{References}

Bessonova, Yu. V., \& Lazebnaia, E. O. (2013). Tsennostnyie predposylki vygoraniia subiekta truda [Value prerequisites for burnout of the subject of labor]. Vygoraniie $i$ professionalizatsiia - Burnout and Professionalization: Collection of research papers, (pp. 29-43). V. V. Lukianov and others (Eds.). Kursk : KGU [in Russian].

Bondarchuk, O. I. (2008). Sotsialno-psykholohichni osnovy osobystisnoho rozvytku kerivnykiv zahalnoosvitnikh navchalnykh zakladiv u profesiinii diialnosti [Social and psychological foundations of a personal development of heads of secondary schools in the professional activity]. Extended abstract of Doctor's thesis. Kyiv [in Ukrainian].

Vodopianova, N. E., Starchenkova, E. S., \& Nasledov, A. D. (2013). Standartizirovannyi oprosnik «Professionalnoie vygoraniie» dlia spetsialistov sotsionomicheskikh professii [Standardized questionnaire "Professional burnout» for specialists in socionomic professions]. Vestnik Sankt-Peterburgskogo universiteta - Bulletin of St. Petersburg University. Series 12. Sociology, 4, 17-27 [in Russian].

Honcharenko, N. V., \& Bilous, M. V. (2018). Psykholohichni osoblyvosti proiavu syndromu «emotsiinoho vyhorannia» $u$ provizoriv-interniv [Psychological peculiarities of pharmacists-interns' emotional burnout syndrome manifestation]. Problemy suchasnoi psykholohii - Problems of Modern Psychology: Collection of Research Pa-

(C) Tavrovetska Nataliia

DOI (article): https://doi.org/10.32626/2227-6246.2020-49.296-321 
DOI: https://doi.org/10.32626/2227-6246.2020-49 2020. ВипУСК 49

pers of Kamianets-Podilskyi National Ivan Ohiienko University and G. S. Kostiuk Institute of Psychology of the National Academy of Educational Sciences of Ukraine, 40, 62-80. DOI 10.32626/22276246.2018-40.62-80 [in Ukrainian].

Karamushka, L. M., \& Hnuskina, H. V. (2018). Psykholohiia profesiinoho vyhorannia pidpryiemtsiv [Psychology of professional burnout of entrepreneurs ]. Kyiv : Lohos [in Ukrainian].

Levit, L. Z. (2016). Psikhologiia razvitiia i realizatsii zhiznennogo potentsiala subiekta [Psychology of the development and realization of life potential of the subject]. Extended abstract of Doctor's thesis. Kiev [in Ukrainian].

Lengle, A. (2008) Emotsionalnoie vygoraniie s pozitsii ekzistentsialnogo analiza [Emotional burnout from the standpoint of existential analysis]. Voprosy psikhologii - Psychology Issues, 2, 3-16 [in Russian].

Fesun, H., Nechytailo, T., \& Kanivets, T. (2019). Vzaiemozviazok komponentiv syndromu «profesiinoho vyhorannia» $\mathrm{z}$ osoblyvostiamy simeinoho statusu $\mathrm{v}$ pedahohiv [Relationship between components of "professional burnout» syndrome with the peculiarities of family status in educators]. Psykholohichni perspektyvy - Psychological Perspectives, 34, 232-248. Retrieved from https://doi.org/10.29038/ 2227-1376-2019-34-232-248 [in Ukrainian].

Freudenberger, H. (1974). Staff Burnout. Journal of Social Issues, 30, 159-165. DOI 10.1111/j.1540-4560.1974.tb00706.x.

Maslach, C. (1976). Burned-out. Human Behavior, 9, 16-22.

Maslach, C., Jackson, S. E., \& Leiter, M. P. (1997). The Maslach burnout inventory Manual. Evaluating stress, (pp. 191-218). Palo Alto, California : Consulting Psychologists Press.

Maslach, C., \& Leiter, M. P. (2016). Burnout. In G. Fink (Ed.). Handbook of Stress: Vol. 1. Stress: Concepts, Cognition, Emotion, and Behavior, (pp. 351-357). Academic Press. DOI 10.1016/B978-0-12-8009512.00044-3.

Тавровецька Наталія. Взаємозв'язок професійного вигорання педагогів з особливостями ціннісно-смислової сфери і життєвої позиції

\section{АНОТАЦІЯ}

Mema cmammi - розглянути теоретичні та практичні підходи у дослідженні професійного й емоційного вигорання педагогів у контексті взаємозв'язку їх ціннісно-смислової сфери й екзистенційного сенсу. Поняття "професійне» й «емоційне вигорання» аналізуються із сучасних позицій,

(C) Tavrovetska Nataliia

DOI (article): https://doi.org/10.32626/2227-6246.2020-49.296-321 
але спираються на відомі теорії Х. Маслач і Н. Водоп'янової. Зазначено, що вигорання в найширшому контексті - це набутий стан психоемоційного та мотиваційного виснаження, спричинений дисбалансом витрат і ресурсів професійної діяльності, що зачіпає ціннісно-мотиваційні основи регуляції поведінки та призводить до тривалого зниження ефективності людини в значущій для неї сфері життєдіяльності.

Для визначення взаємозв'язку між вираженістю профресійного вигорання й особливостями ціннісно-смислових орієнтацій було використано комплекс методів і методик: стандартизований опитувальник «Професійне вигорання» (Н. Водоп'янової й О. Старченкової), Опитувальник життєвих орієнтацій (О. Коржової), методика Ш. Шварца, шкала екзистенції (А. Ленглі, К. Орглер), опитувальник суб'єктивного відчуження (С. Мадді; в адаптації Є. Осіна), тест життєстійкості С. Мадді, копінг-тест (Р. Лазаруса і С. Фолкман), методи кореляційного і факторного аналізу.

Результати дослідження. 3'ясовано, що визнання та заперечення низки ціннісних орієнтирів педагогів значуще пов'язано із симптомами вигорання - вони можуть бути їх діагностичними маркерами, причинами або наслідками. Загалом, вигорання у педагогів супроводжуться прагненням до внутрішньої гармонії, ставленням до здоров'я і безпеки як провідних життєвих принципів, посиленням гедоністичних установок, прагненням до новизни.

Проведено кореляційний аналіз, який установив, що екзистенційна наповненість життя прямо корелює з рівнем особистих і професійних досягнень педагогів $i$, очевидно, є чинником, що протидіє вигоранню. Вираженість вигорання, навпаки, корелює з проявами самовідчуження і втратою сенсу в різних життєвих сфрерах.

У висновках доведено наявність загальних стратегій життєтворення, які регулюють взаємозв'язок професійного вигорання і ціннісносмислових орієнтацій працівників і керівників закладів загальної освіти: виснаження самовдосконаленням; гіпергедонізм; свобода думок і вчинків; гуманістична позиція; відповідність соціальним очікуванням.

Ключові слова: профресійне вигорання, емоційне виснаження, ціннісно-смислові орієнтації, профресійна успішність.

Тавровецкая Наталия. Взаимосвязь профессионального выгорания педагогов с особенностями ценностно-смысловой сферы и жизненной позиции

(C) Tavrovetska Nataliia

DOI (article): https://doi.org/10.32626/2227-6246.2020-49.296-321 


\section{АННОТАЦИЯ}

Цель статьи - рассмотреть теоретические и практические подходы в исследовании профессионального и эмочионального выгорания педагогов в контексте взаимосвязи их иенностно-смысловой среры и экзистенционального смысла. Понятия "профессиональное» и "эмоциональное выгорание» анализируются с современных позиций, но опираются на известные теории Х. Маслач и Н. Водопьяновой. Отмечено, что выгорание в самом широком контексте - это приобретенное состояние психоэмоционального и мотивационного истощения, вызванное дисбалансом расходов и ресурсов профессиональной деятельности, затрагивающим ценностно-мотивационные основы регуляции поведения и приводящим к длительному снижению эфррективности человека в значимой для него срере жизнедеятельности.

Для определения взаимосвязи между выраженностью профессионального выгорания и особенностями ченностно-смысловых ориентаций был использован комплекс методов и методик: стандартизированный опросник "Профессиональное выгорание» (Н. Водопьяновой и Е. Старченковой), опросник жизненных ориентаций (Е. Коржовой), методика Ш. Шварца, икала экзистенции (А. Лэнгли, К. Орглер), опросник субъективного отчуждения (С. Мадди; в адаптации Е. Осина), тест жизнестойкости С. Мадди, копинг-тест (Р. Лазаруса и С. Фолкмана), методы корреляционного и факторного анализа.

Результаты исследования. Выяснено, что признание и отрицание ряда ценностных ориентиров педагогов значимо связано с симптомами выгорания - они могут быть их диагностическими маркерами, причинами или последствиями. В целом, выгорание у педагогов сопровождается стремлением к внутренней гармонии, отношением к здоровью и безопасности как ведущим жизненным принципам, усилением гедонистических установок, стремлением к новизне.

Проведен корреляционный анализ, который установил, что экзистенциальная наполненность жизнью прямо коррелирует с уровнем личных и профессиональных достижений педагогов и, очевидно, является фактором, противодействующим выгоранию. Выраженность выгорания, наоборот, коррелирует с проявлениями самоотчуждения и потерей смысла в различных жизненных сферах.

В выводах доказано наличие общих стратегий жизнетворения, регулирующих взаимосвязь профессионального выгорания и ценностно(C) Tavrovetska Nataliia

DOI (article): https://doi.org/10.32626/2227-6246.2020-49.296-321 
ISSN 2227-6246 (Print)

ISSN 2663-6956 (Online)

ПРОБЛЕМИ СУЧАСНОї ПСИХОЛОГІї

DOI: https://doi.org/10.32626/2227-6246.2020-49

2020. ВИПУСК 49

смысловых ориентаций у педагогов и руководителей общеобразовательных школ: истощение самосовершенствованием; гипергедонизм; свобода мыслей и поступков; гуманистическая позиция; соответствие социальным ожиданиям.

Ключевые слова: профессиональное выгорание, эмочиональное истощение, ценностно-смысловые ориентации, профрессиональная успешHость.

Original manuscript received April 23, 2020

Revised manuscript accepted May 30, 2020

(C) Tavrovetska Nataliia

DOI (article): https://doi.org/10.32626/2227-6246.2020-49.296-321 